2014-03

\title{
Cash holding, trade credit and access to short-term bank finance
}

Kling, G

http://hdl.handle.net/10026.1/11327

10.1016/j.irfa.2014.01.013

International Review of Financial Analysis

Elsevier BV

All content in PEARL is protected by copyright law. Author manuscripts are made available in accordance with publisher policies. Please cite only the published version using the details provided on the item record or document. In the absence of an open licence (e.g. Creative Commons), permissions for further reuse of content should be sought from the publisher or author. 


\title{
Cash holding, trade credit and access to short-term bank finance
}

\author{
Gerhard Kling ${ }^{\mathrm{a}, *}$, Salima Y. Paul ${ }^{\mathrm{b}}$, Eleimon Gonis ${ }^{\mathrm{c}}$ \\ a Department of Financial and Management Studies, School of Oriental and African Studies, University of London, Thornhaugh Street, Russell Square, London WC1H OXG, United Kingdom \\ b University of Plymouth, United Kingdom \\ c University of the West of England, Nationwide Building Society, United Kingdom
}

\section{A R T I C L E I N F O}

\section{Article history:}

Received 11 March 2013

Received in revised form 24 January 2014

Accepted 25 January 2014

Available online 3 February 2014

\section{JEL classification:}

G32

Keywords:

Cash holding

Trade credit

Bank finance

Working capital management

\begin{abstract}
A B S T R A C T
Since 1988 , cash holding of the UK companies has increased from $10.6 \%$ to $16.4 \%$ of total assets. To explain this increase, we develop a panel vector autoregression and analyse the dynamics between cash holding and its closest substitutes, trade credit and short-term bank finance. Impulse response functions confirm the signalling theory, as trade credit facilitates access to bank finance. Firms experiencing liquidity shocks resort to cash or trade credit but not to bank finance. Cash holding improves access to trade credit. Additional cash and trade credit trigger a slowdown of the cash conversion cycle explained by agency theory. Cash-rich firms have accumulated more cash than predicted because of an unexpected decline in short-term debt, stressing the role of banks in explaining the increase in cash holding.
\end{abstract}

(c) 2014 Elsevier Inc. All rights reserved.

\section{Introduction}

Bates, Kahle, and Stulz (2009) show that average cash ratios, defined as cash and cash equivalents relative to total assets, of the US firms increased from $10.5 \%$ to $23.2 \%$ in the period from 1980 to 2006 . We analyse the UK listed companies in the period from 1988 to 2008 and find an increase in average cash ratios from $10.6 \%$ to $16.4 \%$. In contrast, Ferreira and Vilela (2004: 303) state that "it is not possible to identify any clear trend" in cash holding in EMU countries between 1987 and 2000. Yet their investigation period does not include the Dot-com bubble or the recent financial crisis. The literature on cash holding focuses on four motives determining the demand for cash: transaction, precaution, investment opportunities, and self-interest (Graham \& Harvey, 2001; Harford, 1999; Harford, Mansi, \& Maxwell, 2008; Keynes, 1936; Myers, 1977; Myers \& Majluf, 1984). The motive driven view understates the importance of a supply-side explanation. Cash holding might increase due to a lack of alternative funding. The main characteristic of cash is its flexibility, as it is available instantaneously (Ang \& Smedema, 2011). The closest substitutes in terms of instantaneous access are trade credit and short-term bank finance. Of course, reducing dividends or selling assets can provide liquidity - but these

\footnotetext{
* Corresponding author. Tel.: +44207898 4821.

E-mail address: gk17@soas.ac.uk (G. Kling).
}

options are not instantaneous and costly due to signalling effects and transaction costs (Keynes, 1936; Opler, Pinkowitz, Stulz, \& Williamson, 1999).

This paper considers the demand and supply-side explanations of cash holding by analysing the dynamics between cash holding and its closest substitutes, trade credit and short-term bank finance. To capture a firm's short-term liquidity need, we determine the cash conversion cycle (CCC). We develop a panel vector autoregression (VAR) accounting for the complex interrelationships between cash holding, trade credit, short-term bank finance and liquidity needs. This novel method leads to three contributions: (1) distinguishing between the demand and supply-side of liquidity, (2) extending the dynamic model of cash holding, and (3) analysing the mismatch of expectations concerning access to short-term bank finance.

The literature on cash holding mainly relies on demand-side explanations (Opler et al., 1999); however, Bates et al. (2009) contend that there was no shift in the demand for cash that could explain the recent increase in cash holding. They argue that firm characteristics changed, increasing cash holding due to riskier cash flows, higher R\&D intensity and lower working capital requirements (i.e. lower inventory and accounts receivable). Bates et al. (2009) do not consider the role of trade credit granted by suppliers and short-term bank finance. Both sources of short-term funding have declined sharply in the UK during the investigation period. Hence, the supply-side is essential in understanding the recent increase in cash holding. After specifying a panel 
VAR, we determine impulse response functions to differentiate between demand and supply-side effects. This provides insights into the dynamic relationships between cash holding, firms' liquidity needs, trade credit and short-term bank finance.

This paper extends the dynamic model of cash holding by incorporating additional lags based on information criteria (Opler et al., 1999; Ozkan, Ozkan, \& N., 2004). Static models are biased because past cash holding affects current cash holding. Apart from improving the econometric validity of the model, we gain insights into the dynamic relationship between the demand and supply of liquidity. In particular, we specify a panel vector autoregression (VAR) with four dependent variables: cash holding, the CCC to capture a firm's liquidity need, trade credit and short-term bank finance. The literature on trade credit applies panel VARs to aggregated data (Nilsen, 2002). In contrast, our panel VAR refers to the firm-level and deals with the inherent endogeneity and firm heterogeneity by applying a system GMM estimation (Arellano \& Bond, 1991; Ozkan et al., 2004). Granger causality tests show that the four variables are endogenous. Consequently, a singleequation approach suffers from an endogeneity bias (Opler et al., 1999; Ozkan et al., 2004). In particular, the liquidity need measured by the CCC is endogenous; hence, using the CCC as an explanatory variable without a time lag violates weak exogeneity (Deloof, 2001).

In spite of delivering accurate one-step ahead forecasts for the average firm, the model understates the rapid accumulation of cash by cash-rich firms defined as belonging to the 75-percentile in 1988. Hence, we impose a liquidity constraint, which states that cash holding has to be sufficient to cover net working capital given expected access to external finance. We show that cash-rich firms suffer from lower than expected access to external finance. Accordingly, the pronounced increase in cash holding can be explained by a mismatch of expectations, a novel finding.

This paper has the following structure: section two reviews the literature on the relationship between cash holding, trade credit, access to short-term bank finance and the CCC; section three discusses the dataset and construction of variables; section four introduces the panel VAR and shows our findings followed by robustness checks and concluding remarks.

\section{Literature review}

\subsection{The motive-driven view of cash holding}

Empirical studies use net working capital, which includes trade credit, as an explanatory variable (e.g. Ferreira \& Vilela, 2004; Opler et al., 1999). Yet, the literature does not consider the role of trade credit as a source of external funding explicitly. In contrast, the literature on the relationship between trade credit and access to bank finance discussed in the next section largely ignores the role of cash holding. Consequently, it seems to be essential to combine both strands of the literature and analyse the demand and supply-side of liquidity. The literature on cash holding identifies the following theories: transaction cost theory, information asymmetry between debt and equity holders, and agency costs due to a conflict of interest between shareholders and managers.

Transaction cost theory argues that transaction costs due to converting cash substitutes into cash justify cash holding (Keynes, 1936; Miller \& Orr, 1966; Tobin, 1956). There are several hypotheses related to the transaction cost theory highlighted by Opler et al. (1999). Some of these hypotheses refer to long-term decision making not relevant for meeting short-term liquidity needs due to the lack of instantaneous access. For instance, the asset sales of diversified companies and the reduction of dividend payments cannot substitute cash holding in the short-term (Ang \& Smedema, 2011). Information asymmetry between debt and equity holders could explain cash holding. Myers and Majluf (1984) contend that securities might be undervalued by outsiders due to the lack of access to information. R\&D expenses serve as a proxy for projects with a high degree of information asymmetry. As we focus on the instantaneous availability of cash and its closest substitutes, R\&D expenses and some forms of external finance (e.g. equity issues) are not a relevant option to meet short-term

Table 1

Descriptive statistics.

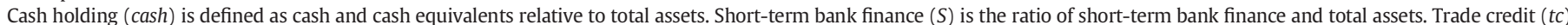

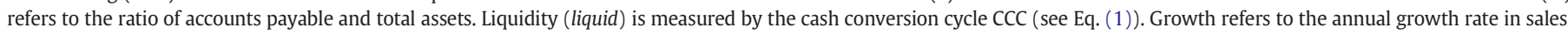

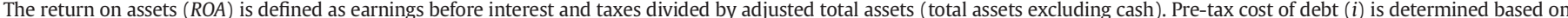

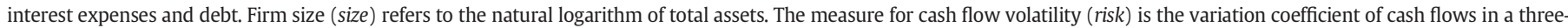

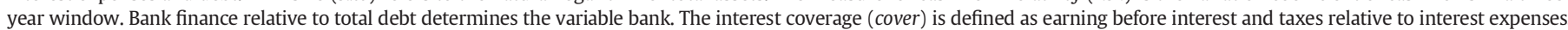

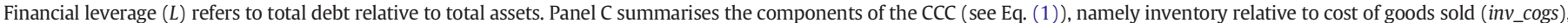

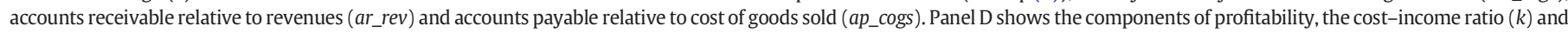

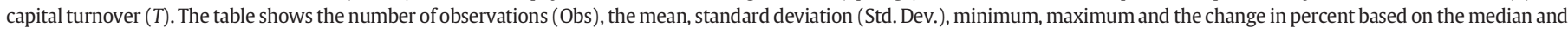
mean from 1988 to 2008 .

\begin{tabular}{|c|c|c|c|c|c|c|c|}
\hline Variable & Obs & Mean & Std. Dev. & Min & Max & Median change & Average change \\
\hline \multicolumn{8}{|c|}{ Panel A: endogenous variables } \\
\hline cash & 14,073 & 0.158 & 0.154 & 0.006 & 0.481 & $71.0 \%$ & $54.7 \%$ \\
\hline$S$ & 13,801 & 0.228 & 0.124 & 0.062 & 0.453 & $-23.6 \%$ & $-18.4 \%$ \\
\hline tc & 13,803 & 0.118 & 0.082 & 0.019 & 0.271 & $-48.7 \%$ & $-34.8 \%$ \\
\hline liquid & 13,105 & 0.212 & 0.146 & 0.017 & 0.497 & $-25.3 \%$ & $-15.6 \%$ \\
\hline \multicolumn{8}{|c|}{ Panel B: control variables } \\
\hline growth & 12,511 & 0.160 & 0.269 & -0.184 & 0.732 & $-15.3 \%$ & $-13.4 \%$ \\
\hline$R O A$ & 13,977 & -0.013 & 0.263 & -0.643 & 0.243 & $-66.7 \%$ & $-133.1 \%$ \\
\hline$i$ & 12,116 & 0.101 & 0.065 & 0.032 & 0.251 & $-28.0 \%$ & $-20.3 \%$ \\
\hline size & 14,631 & 10.721 & 1.966 & 7.877 & 14.028 & $-0.8 \%$ & $-1.6 \%$ \\
\hline risk & 14,515 & 0.930 & 0.931 & 0.136 & 3.077 & $139.2 \%$ & $106.5 \%$ \\
\hline bank & 6518 & 0.255 & 0.324 & 0.001 & 0.880 & $-72.2 \%$ & $-13.1 \%$ \\
\hline cover & 12,776 & 7.086 & 22.219 & -32.000 & 53.329 & $-68.6 \%$ & $-73.5 \%$ \\
\hline$L$ & 14,622 & 0.156 & 0.143 & 0.000 & 0.417 & $0.0 \%$ & $10.6 \%$ \\
\hline \multicolumn{8}{|c|}{ Panel C: components of the cash conversion cycle } \\
\hline inv_cogs & 14,444 & 0.090 & 0.088 & 0.000 & 0.249 & $-85.1 \%$ & $-55.3 \%$ \\
\hline ar_rev & 13,730 & 0.210 & 0.116 & 0.057 & 0.450 & $1.5 \%$ & $10.6 \%$ \\
\hline ap_cogs & 13,714 & 0.107 & 0.055 & 0.034 & 0.208 & $-28.7 \%$ & $-19.5 \%$ \\
\hline \multicolumn{8}{|c|}{ Panel D: components of profitability (ROA) } \\
\hline$k$ & 13,704 & 1.024 & 0.272 & 0.780 & 1.715 & $7.9 \%$ & $21.3 \%$ \\
\hline$T$ & 13,490 & 2.063 & 1.474 & 0.192 & 4.785 & $-53.4 \%$ & $-40.3 \%$ \\
\hline
\end{tabular}




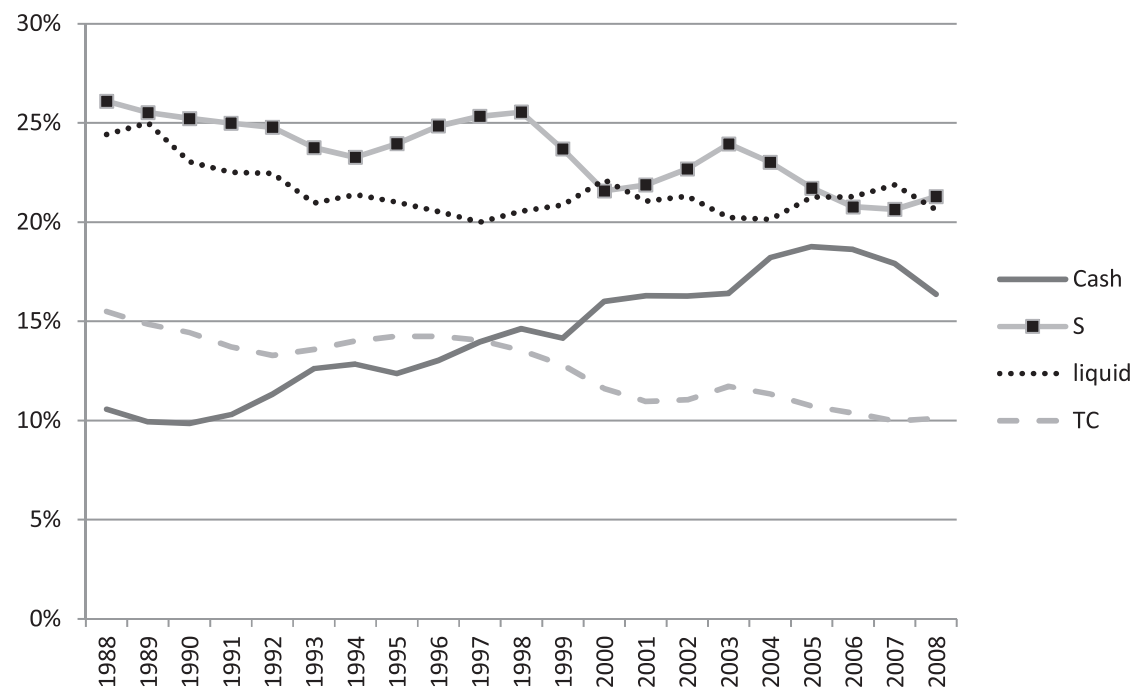

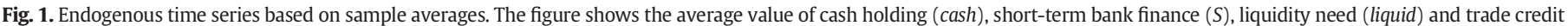
$(t c)$ of the whole sample. All variables are in percent of total assets.

liquidity needs. Finally, agency costs due to conflicts of interest between managers and shareholders are of a long-term nature such as empire building through acquisitions (Jensen, 1986). However, there might be a short-term equivalent, namely the incentive to improve working capital management, which this paper discusses.

The empirical evidence for transaction costs and information asymmetry and the related motives of transaction, precaution, and investment opportunities stress the predominant role of transactions in explaining cash holding (Beltz \& Frank, 1996; Deloof, 2001; John, 1993). D'Mello, Krishnaswami, and Larkin (2008) show that firms with easy internal financing hold little cash, whereas firms with high growth opportunities and volatile cash flows hold more cash. Based on the theoretical considerations, costs of holding cash (opportunity costs), cost of external finance, volatility of cash flows, firm size and growth opportunities determine cash holding. Holding cash is mainly driven by the need to execute transactions - but prevention could be relevant in the case of small firms in unstable environments. Opler et al. (1999) analyse the determinants of cash holding in the US and uncover that cash holding is negatively associated with firm size and positively associated with investment opportunities, risk and the difficulty in obtaining external finance measured by high financial leverage.

\subsection{Access to short-term bank finance and trade credit}

The literature on trade credit and short-term bank finance falls into two main categories: (1) the substitution hypothesis pioneered by Meltzer (1960) and (2) the complementary view based on signalling theory and the underlying information asymmetry between suppliers and banks (Bias \& Gollier, 1997; Jain, 2001). Firms with access to bank finance need less trade credit, which is usually more expensive; thus, there is a substitution effect (Bias \& Gollier, 1997). Yet, the literature contends that substitution is the direct effect, whereas trade credit has an indirect signalling effect. We test the relationship between trade credit and short-term bank finance, which could confirm the substitution effect or the signalling theory. In addition, Petersen and Rajan (1997) emphasise that there is a positive correlation between the firm's willingness to provide trade credit and access to short-term finance. Amid the financial crisis, this effect could be of importance, as firms might face pressure from two sides: restricted access to bank finance due to the credit crunch and less trade credit granted by suppliers, which in turn suffer from a lack of short-term liquidity.

\subsection{The need for liquidity based on the cash conversion cycle (CCC)}

The cash holding literature has tested the transaction motive using sales as a proxy, which should reflect the firm's business activities and associated transaction needs. Using sales as a proxy is problematic, since sales and firm size are correlated. Hence, it is difficult to distinguish between size effects and transaction needs. For instance, firms with low accounts receivable and high sales do not need much cash, as customers tend to pay immediately (e.g. retailers have high sales and low accounts receivable, which results in negative net working capital). Accordingly, to determine the liquidity needs of a firm, we follow Deloof (2001) and calculate the CCC of each firm. The CCC, which goes back to Gitman (1974), is a dynamic measure of liquidity and better than static measures such as net working capital relative to total assets. Most studies of the CCC focus on its impact on profitability measures confirming a negative relationship (Wang, 2002). So a smaller CCC improves profitability, which in turn enhances shareholder value.

\section{The method of sampling and construction of variables}

We collected annual data from Datastream on all companies listed on the London Stock Exchange (Main Market) in the period from 1988 to 2008. To cross-check accounting data, we used annual reports. After removing regulated industries such as utilities and financial institutions, the sample consists of 1343 companies. Due to missing values, the maximum number of firm-year observations is 14631. As the number of listed companies changed during the investigation period, the robustness check considers a potential survivorship bias. The four endogenous variables refer to cash ratios defined as cash and cash equivalents relative to total assets (cash), trade credit granted by suppliers defined as accounts payable relative to total assets $(t c)$, short-term bank finance relative to total assets $(S)$, and the firm's liquidity need based on the CCC (liquid). Eq. (1) defines the CCC, which follows Deloof (2001).

$\operatorname{liquid}_{i t}=\frac{I N V_{i t}}{\operatorname{COGS}_{i t}}+\frac{A R_{i t}}{R E V_{i t}}-\frac{A P_{i t}}{C O G S_{i t}}$.

In line with prior research, we included sales growth (growth), firm size defined as the natural logarithm of total assets (size), and profitability measured by the return on adjusted total assets $(R O A)$. To remove the effect of non-operating assets including excess cash, we adjust total assets to reflect only net property, plant and equipment and net 
Table 2

Annual averages.

The table provides annual averages for selected variables.

\begin{tabular}{|c|c|c|c|c|c|c|c|c|c|c|c|c|c|}
\hline Year & growth & $R O A$ & $i$ & size & risk & bank & cover & $L$ & inv_cogs & ar_rev & ap_cogs & $k$ & $T$ \\
\hline 1988 & - & 0.154 & 0.118 & 10.950 & 0.418 & 0.321 & 17.334 & 0.142 & 0.161 & 0.198 & 0.128 & 0.880 & 2.803 \\
\hline 1989 & 0.231 & 0.138 & 0.124 & 11.028 & 0.505 & 0.246 & 13.688 & 0.168 & 0.152 & 0.205 & 0.125 & 0.894 & 2.633 \\
\hline 1990 & 0.129 & 0.126 & 0.145 & 11.149 & 0.614 & 0.273 & 9.796 & 0.177 & 0.144 & 0.191 & 0.119 & 0.910 & 2.565 \\
\hline 1991 & 0.040 & 0.092 & 0.142 & 11.136 & 0.624 & 0.313 & 8.518 & 0.182 & 0.136 & 0.187 & 0.110 & 0.935 & 2.479 \\
\hline 1992 & 0.047 & 0.081 & 0.131 & 11.134 & 0.670 & 0.268 & 9.005 & 0.185 & 0.135 & 0.190 & 0.109 & 0.939 & 2.407 \\
\hline 1993 & 0.101 & 0.083 & 0.121 & 11.206 & 0.662 & 0.265 & 9.881 & 0.165 & 0.126 & 0.187 & 0.113 & 0.938 & 2.425 \\
\hline 1994 & 0.125 & 0.093 & 0.104 & 11.261 & 0.672 & 0.239 & 12.035 & 0.154 & 0.126 & 0.195 & 0.118 & 0.940 & 2.407 \\
\hline 1995 & 0.177 & 0.096 & 0.103 & 11.324 & 0.620 & 0.222 & 12.135 & 0.158 & 0.124 & 0.194 & 0.117 & 0.937 & 2.500 \\
\hline 1996 & 0.155 & 0.090 & 0.109 & 10.915 & 0.696 & 0.213 & 11.550 & 0.154 & 0.112 & 0.194 & 0.114 & 0.958 & 2.550 \\
\hline 1997 & 0.134 & 0.083 & 0.108 & 10.844 & 0.768 & 0.236 & 12.070 & 0.152 & 0.108 & 0.197 & 0.115 & 0.973 & 2.582 \\
\hline 1998 & 0.130 & 0.039 & 0.100 & 10.887 & 0.823 & 0.236 & 11.129 & 0.167 & 0.102 & 0.202 & 0.111 & 0.986 & 2.438 \\
\hline 1999 & 0.136 & 0.023 & 0.101 & 10.869 & 0.850 & 0.234 & 9.035 & 0.169 & 0.098 & 0.207 & 0.110 & 0.996 & 2.177 \\
\hline 2000 & 0.184 & -0.029 & 0.100 & 10.842 & 0.953 & 0.239 & 6.894 & 0.155 & 0.089 & 0.222 & 0.110 & 1.044 & 1.948 \\
\hline 2001 & 0.179 & -0.072 & 0.100 & 10.752 & 0.917 & 0.254 & 2.505 & 0.157 & 0.082 & 0.212 & 0.102 & 1.082 & 1.917 \\
\hline 2002 & 0.111 & -0.098 & 0.091 & 10.532 & 0.867 & 0.246 & 1.224 & 0.164 & 0.077 & 0.211 & 0.096 & 1.100 & 1.938 \\
\hline 2003 & 0.131 & -0.089 & 0.088 & 10.383 & 0.850 & 0.252 & 3.085 & 0.165 & 0.071 & 0.209 & 0.097 & 1.087 & 2.025 \\
\hline 2004 & 0.163 & -0.055 & 0.091 & 10.348 & 0.854 & 0.260 & 6.462 & 0.152 & 0.071 & 0.209 & 0.103 & 1.048 & 2.042 \\
\hline 2005 & 0.189 & -0.057 & 0.093 & 10.395 & 0.816 & 0.265 & 6.145 & 0.142 & 0.069 & 0.221 & 0.105 & 1.054 & 1.907 \\
\hline 2006 & 0.207 & -0.051 & 0.092 & 10.490 & 0.868 & 0.268 & 5.172 & 0.142 & 0.069 & 0.224 & 0.106 & 1.060 & 1.803 \\
\hline 2007 & 0.197 & -0.053 & 0.095 & 10.632 & 0.864 & 0.269 & 5.286 & 0.147 & 0.068 & 0.227 & 0.104 & 1.067 & 1.700 \\
\hline 2008 & 0.200 & -0.051 & 0.094 & 10.774 & 0.863 & 0.279 & 4.591 & 0.157 & 0.072 & 0.219 & 0.103 & 1.067 & 1.672 \\
\hline Total & 0.160 & -0.013 & 0.101 & 10.721 & 0.805 & 0.255 & 7.086 & 0.156 & 0.090 & 0.210 & 0.107 & 1.024 & 2.063 \\
\hline
\end{tabular}

operating working capital. Pre-tax cost of debt $(i)$ accounts for the cost of external debt finance, and it is also used as a proxy for the opportunity cost of cash holding, as cash substitutes external debt finance (Opler et al., 1999). The following proxies incorporate firms' financial risk: financial leverage defined as total debt relative to total assets $(L)$ and interest coverage defined as earnings before interest and taxes (EBIT) relative to interest expenses (cover). Some studies include the ratio of bank finance to total debt (bank) to evaluate the monitoring role of banks, which is also common in the trade credit literature (Gama, Mateus, \& Teixeira, 2008). We include a measure for the uncertainty of cash flows defined as the variation coefficient of EBIT in a threeyear window (risk). The definition of cash flow risk differs from Bates et al. (2009), for they refer to the mean of the standard deviation of cash flows in an industry based on 2-digit SIC codes. Their measure captures the industry-specific cash flow uncertainty but does not reflect idiosyncratic risk. Moreover, variation coefficients are robust if means differ across firms. In addition, we determine the variables needed to calculate the CCC, namely inventory relative to cost of goods sold (inv_cogs), accounts receivable relative to revenues (ar_rev) and accounts payable relative to cost of goods sold (ap_cogs). To illustrate the underlying drivers of firms' profitability, the descriptive statistics also report the cost-income ratio defined as operating costs relative to operating income $(k)$ and capital turnover defined as sales relative to total operating assets $(T)$.

\section{Empirical analysis}

\subsection{Descriptive findings}

Table 1 provides descriptive statistics for the whole investigation period, and Fig. 1 depicts the time series of cash holding, the CCC, trade credit and short-term bank finance, revealing an increase in cash ratios from $10.6 \%$ to $16.4 \%$. Apparently, cash holding increased long before the current financial crisis, reaching its peak in 2005. The need for liquidity determined by the CCC (liquid) exhibited an initial decline until 1993 but remained stable thereafter. Fig. 1 suggests that firms faced a constant liquidity need, whereas short-term bank finance $(S)$ and trade credit ( $t c$ ) exhibited a pronounced decline.

The question arises why the CCC has remained on a stable albeit high level in spite of various improvements in working capital management. Table 2 shows that inventory management improved substantially (inv_cogs) - maybe due to better production and transport technologies.
Accounts receivable relative to revenues ( $a r_{-} r e v$ ) remained unchanged indicating that the UK firms had to provide trade credit to their customers to maintain sales and remain competitive. This finding supports Nadiri's (1969) model and shows that trade credit is part of the selling process. Trade credit provided by suppliers relative to cost of goods sold (ap_cogs) dropped; thus, the UK firms provided trade credit to their customers to sustain sales - but found it harder to get trade credit from their suppliers.

Diminished capital turnover $(T)$ and higher cost-income ratios $(k)$ reduce profitability $(R O A)$. Firm size (size) remained on a similar level, whereas sales growth fluctuated due to business cycles. The importance of bank loans (bank) declined in line with control variables that affect access to external finance. Interest coverage (cover) worsened indicating a lack of earnings to cover interest expenses. The latter indicates that the UK companies might find it harder to get access to bank finance. The variation coefficient of cash flows (risk) increased over time. Cost of debt $(i)$ fluctuated considerably in the investigation period - but compared to the 1980s cost of debt declined. In contrast to their US counterparts, the UK firms did not exhibit negative net debt in spite of more cash holding, as financial leverage $(L)$ remained stable (Bates et al., 2009).

\subsection{Panel vector autocorrelation (VAR)}

To capture the dynamic relationships between cash holding, the CCC, trade credit and short-term bank finance, we specify a panel VAR with three lags based on the Bayesian Schwarz information criterion. We estimate the panel VAR with panel OLS, which ignores firmspecific effects, and system GMM based on the dynamic panel estimator developed by Arellano and Bond (1991) that considers firm-specific effects. ${ }^{1}$ The model includes a set of lagged exogenous control variables. By lagging the control variables by one year, we ensure weak exogeneity, as the variables are predetermined. We include sales growth (growth), profitability $(R O A)$, and firm size (size). To evaluate the firm's financial viability, the model considers cost of debt $(i)$, interest coverage (cover), financial leverage $(L)$, and uncertainty of cash flows (risk). The relative importance of bank finance (bank) serves as a measure for the firm's relationship with banks. The column vector $\mathbf{z}_{\mathbf{i t}}$

\footnotetext{
${ }^{1}$ We cannot include firm-specific fixed effects, for dummy variables would be correlated with the lagged endogenous time series. Ozkan et al. (2004) address the related estimation issues and apply Arellano and Bond's (1991) GMM estimator.
} 
Table 3

The panel VAR based on GMM and POLS.

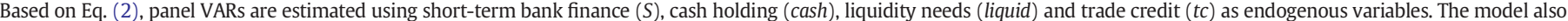

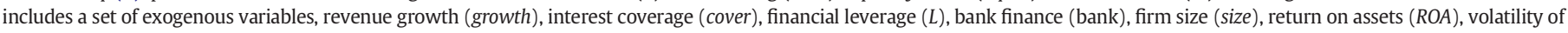

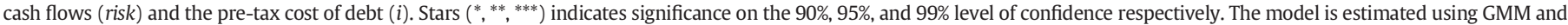

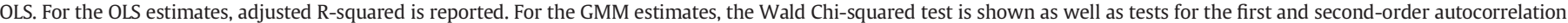
(Corr1, Corr2). The table also provides the p-values of the Sargan and Hansen tests.

\begin{tabular}{|c|c|c|c|c|c|c|c|c|}
\hline \multicolumn{5}{|l|}{ GMM estimation } & \multicolumn{4}{|c|}{ Panel VAR using panel OLS } \\
\hline & $S$ & cash & liquid & tc & $S$ & cash & liquid & tc \\
\hline$S_{t-1}$ & $0.408^{* * *}$ & 0.005 & $-0.062^{* * *}$ & $0.016^{*}$ & $0.647^{* * *}$ & $0.033^{* *}$ & -0.022 & $0.016^{* *}$ \\
\hline$S_{t}-2$ & -0.006 & -0.015 & -0.006 & -0.007 & $0.080^{* * *}$ & 0.016 & 0.001 & $-0.018^{* *}$ \\
\hline$S_{t-3}$ & -0.004 & -0.020 & -0.004 & -0.003 & $0.109^{* * *}$ & -0.011 & -0.020 & 0.001 \\
\hline $\operatorname{cash}_{\mathrm{t}-1}$ & 0.001 & $0.412^{* * *}$ & $0.109^{* * *}$ & $0.060^{* * *}$ & 0.006 & $0.610^{* * *}$ & $0.035^{* *}$ & 0.003 \\
\hline $\operatorname{cash}_{\mathrm{t}-2}$ & 0.000 & 0.021 & 0.006 & $0.028^{* * *}$ & 0.013 & $0.106^{* * *}$ & -0.020 & $0.016^{* *}$ \\
\hline $\operatorname{cash}_{\mathrm{t}-3}$ & -0.004 & -0.023 & -0.015 & -0.011 & $0.026^{* *}$ & $0.070^{* * *}$ & 0.005 & $-0.019^{* * *}$ \\
\hline liquid $_{\mathrm{t}-1}$ & $-0.053^{* *}$ & $0.109^{* * *}$ & $0.219^{* * *}$ & $0.069^{* * *}$ & -0.024 & -0.002 & $0.571^{* * *}$ & -0.007 \\
\hline liquid $_{\mathrm{t}-2}$ & $-0.036^{*}$ & 0.016 & -0.023 & $0.034^{* * * *}$ & -0.017 & 0.004 & $0.212^{* * * *}$ & 0.005 \\
\hline liquid $_{\mathrm{t}-3}$ & 0.023 & 0.010 & $-0.050^{* * *}$ & 0.007 & 0.020 & 0.004 & $0.116^{* * *}$ & -0.004 \\
\hline$t c_{\mathrm{t}-1}$ & $0.123^{* * *}$ & $0.250^{* * *}$ & $0.175^{* * *}$ & $0.502^{* * *}$ & $0.123^{* * *}$ & $-0.059^{*}$ & -0.016 & $0.732^{* * *}$ \\
\hline$t c_{\mathrm{t}-2}$ & -0.052 & 0.022 & $0.090^{* *}$ & $0.080^{* * *}$ & $-0.121^{* * *}$ & -0.037 & 0.056 & $0.146^{* * *}$ \\
\hline tc & 0.010 & -0.005 & -0.011 & -0.002 & 0.015 & $0.074^{* *}$ & -0.031 & $0.047^{* * *}$ \\
\hline growth $_{\mathrm{t}-1}$ & -0.005 & 0.010 & -0.004 & $-0.008^{* * *}$ & $-0.011^{* *}$ & -0.005 & $-0.029 * * *$ & $-0.008^{* * *}$ \\
\hline cover $_{\mathrm{t}-1}$ & $-0.000^{* *}$ & $-0.000^{* * *}$ & 0.000 & $-0.000^{* * *}$ & $-0.000^{* * *}$ & 0.000 & 0.000 & $-0.000^{* * *}$ \\
\hline$L_{\mathrm{t}-1}$ & $-0.188^{* * *}$ & $0.104^{* * * *}$ & 0.021 & -0.011 & $-0.043^{* * *}$ & -0.006 & 0.013 & $-0.022^{* * *}$ \\
\hline bank $_{\mathrm{t}-1}$ & 0.006 & -0.003 & $-0.008^{*}$ & -0.001 & $-0.007^{* *}$ & 0.000 & -0.002 & 0.001 \\
\hline size $_{\mathrm{t}-1}$ & $0.014^{* * *}$ & $-0.016^{* * *}$ & $-0.018^{* * *}$ & 0.002 & 0.000 & $-0.001^{*}$ & $-0.002^{* * *}$ & 0.000 \\
\hline$R O A_{\mathrm{t}-1}$ & 0.012 & $0.035^{* *}$ & $0.032^{* *}$ & $0.021^{* * *}$ & 0.009 & $-0.032^{* * *}$ & $0.044^{* * *}$ & 0.001 \\
\hline risk $_{\mathrm{t}-1}$ & -0.001 & $-0.005^{* *}$ & 0.003 & -0.001 & $0.003^{* *}$ & 0.000 & 0.000 & 0.000 \\
\hline$i_{\mathrm{t}-1}$ & -0.015 & $0.109^{* * *}$ & $0.071^{* *}$ & 0.005 & -0.013 & $0.093^{* * *}$ & $0.071^{* * * *}$ & -0.002 \\
\hline Constant & 0.028 & $0.166^{* * *}$ & $0.349^{* * *}$ & 0.001 & $0.049^{* * * *}$ & $0.024^{* *}$ & $0.037^{* * *}$ & $0.014^{* * *}$ \\
\hline Adjusted $\mathrm{R}^{2}$ & - & - & - & - & 0.637 & 0.584 & 0.759 & 0.844 \\
\hline Wald $\mathrm{Ch}^{2}$ & $165.12^{* * *}$ & $220.7^{* * *}$ & $150.16^{* * *}$ & $230.86^{* * *}$ & - & - & - & - \\
\hline Corr1 & $-10.38^{* * *}$ & $-9.14^{* * *}$ & $-6.10^{* * *}$ & $-8.12^{* * *}$ & - & - & - & - \\
\hline Corr2 & -0.28 & -1.69 & -0.78 & -1.11 & - & - & - & - \\
\hline Sargan (p-value) & 0.000 & 0.000 & 0.000 & 0.000 & - & - & - & - \\
\hline Hansen (p-value) & 0.239 & 0.846 & 0.592 & 0.314 & - & - & - & - \\
\hline
\end{tabular}

incorporates the set of control variables, and the column vector $\mathbf{y}_{\text {it }}$ refers to the four dependent variables. Therefore, the panel VAR with four equations takes the following form.

$$
\left(\begin{array}{c}
S_{i t} \\
\operatorname{cash}_{i t} \\
\text { liquid }_{i t} \\
\text { tc }_{i t}
\end{array}\right)=\mathbf{y}_{\mathbf{i t}}=\alpha+\sum_{j=1}^{p} \Gamma \mathbf{y}_{\mathbf{i t}-\mathbf{j}}+\exists \mathbf{z}_{\mathbf{i t}-1}+\boldsymbol{\theta}_{\mathbf{i}}+\boldsymbol{\varepsilon}_{\mathbf{i t}} .
$$

Our model extends Ozkan et al. (2004) dynamic panel data model by including additional lags as suggested by the Bayesian information criterion and by adding three dependent variables. All eigenvalues lie inside the unit circle, which fulfils the stability condition of the VAR. We test the four dependent variables for unit-roots using the Fisher-type panel test based on an augmented Dickey-Fuller test. This test also considers deterministic trends and cross-sectional differences (firmspecific effects). The test statistic has a p-value of 0.000 and indicates that the four dependent variables are not unit-roots, which ensures that the panel VAR in levels is appropriate. ${ }^{2}$

Table 3 reports the coefficients of the panel VAR based on panel OLS without firm-specific effects and GMM. The results differ substantially, which underline the importance of firm-specific effects and the resulting bias of the least squares estimator. Wald tests reported for the GMM results show that the models have explanatory power. To evaluate the quality of the instruments used for the GMM estimation, Table 3 shows the autocorrelation tests for the first and second lag, the Sargan and the Hansen test. Valid instruments have to be exogenous; hence, the second-order autocorrelation (Corr2) has to be negligible, which is the case, as the tests fail to reject the null hypothesis. ${ }^{3}$ The

\footnotetext{
2 Detailed results including eigenvalues and unit-root tests are available from the authors on request.

${ }^{3}$ This test is robust in the presence of heteroskedasticity.
}

Sargan and the Hansen tests focus on the overidentification restrictions and assess whether the set of instruments is appropriate. The issue is that the Sargan test assumes homoskedastic errors, whereas the Hansen test is robust. This explains why both tests differ. Accordingly, we use a robust estimation of the variance covariance matrix. The Hansen tests could not reject the null hypothesis that the overidentifying restrictions are valid. ${ }^{4}$ In line with Ozkan et al. (2004), Opler et al. (1999) and Harford et al. (2008), the models confirm a high correlation coefficient between current and past levels of cash holding of 0.61 (first lag). Moreover, short-term debt exhibits a similar level of autocorrelation. Accordingly, controlling for lagged variables is essential to obtain reliable estimates. The OLS estimate of the panel VAR shows a high model fit with adjusted R-squared of $64 \%$ for short-term finance, $58 \%$ for cash holding, $76 \%$ for the liquidity measure and $84 \%$ for trade credit.

Table 3 shows that some control variables have a statistically significant effect. Firms with high growth in the past year obtain less trade credit, which shows that access to trade credit cannot be relied upon to finance continuing growth. Interest coverage has a significant but very small effect on all time series except the CCC. Firms with high financial leverage exhibit significantly less short-term bank finance and more cash holding, which might be driven by banks denying access to additional short-term lending, and firms holding cash as an alternative funding source. Larger firms have better access to bank finance and hold less cash, in line with prior research (except Harford et al., 2008). There is also a size advantage related to the CCC, which might be due to the stronger negotiating power of larger firms when dealing with suppliers. Profitability increases cash holding, which could be explained by higher cash generation. Trade credit and the CCC increase with profitability. The first relationship can be interpreted as a supply-side effect,

\footnotetext{
4 Apart from using the first-differenced time series as suggested by Arellano and Bond (1991), which are not always good instruments, we also tried a Helmert's transformation - but the results did not differ (Arellano \& Bover, 1995).
} 
Table 4

Granger causality tests and cumulated impulse response functions.

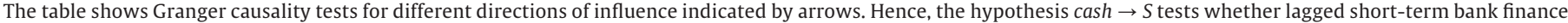

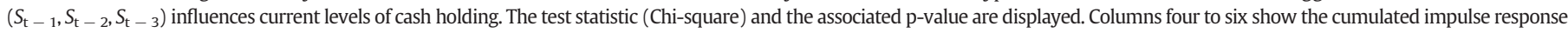

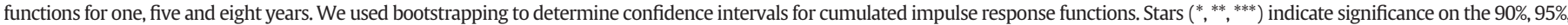

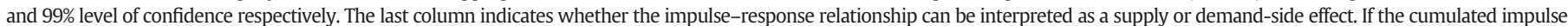
response function is not significant, we do not provide an interpretation.

\begin{tabular}{|c|c|c|c|c|c|c|}
\hline \multicolumn{3}{|c|}{ Granger causality tests } & \multicolumn{4}{|c|}{ Cumulated impulse response function } \\
\hline Null hypotheses & Chi-square & p-value & 1-year & 5-years & 8-years & Interpretation \\
\hline cash $\rightarrow S$ & 0.06 & 1.00 & 0.01 & -0.01 & 0.02 & - \\
\hline liquid $\rightarrow S$ & 11.29 & 0.01 & -0.04 & 0.10 & 0.12 & - \\
\hline$t c \rightarrow S$ & 8.29 & 0.04 & $0.17^{*}$ & $0.54^{*}$ & $0.64^{*}$ & Supply \\
\hline$S \rightarrow$ cash & 1.88 & 0.60 & -0.03 & -0.05 & -0.06 & - \\
\hline liquid $\rightarrow$ cash & 24.66 & 0.00 & $0.08^{*}$ & $0.24^{*}$ & $0.25^{*}$ & Demand \\
\hline tc $\rightarrow$ cash & 27.53 & 0.00 & 0.10 & 0.43 & 0.48 & - \\
\hline$S \rightarrow$ liquid & 10.24 & 0.02 & -0.02 & -0.10 & -0.11 & - \\
\hline cash $\rightarrow$ liquid & 36.17 & 0.00 & $0.09^{* * * *}$ & $0.33^{* * *}$ & $0.34^{* * *}$ & Agency/demand \\
\hline tc $\rightarrow$ liquid & 23.36 & 0.00 & $0.18^{* *}$ & $0.68^{* * *}$ & $0.74^{* * *}$ & Agency/demand \\
\hline$S \rightarrow t c$ & 3.82 & 0.28 & 0.01 & -0.07 & -0.09 & \\
\hline cash $\rightarrow$ tc & 55.43 & 0.00 & $0.04^{* *}$ & $0.12^{*}$ & $0.14^{*}$ & Supply \\
\hline liquid $\rightarrow$ tc & 57.76 & 0.00 & $0.06^{* * * *}$ & $0.20^{* * * *}$ & $0.22^{* * *}$ & Demand \\
\hline
\end{tabular}

as suppliers might be more willing to grant trade credit to a profitable firm. The second effect could indicate that firms with high profitability lack the need to improve working capital management. In contrast to Bates et al. (2009), our measure of cash flow risk has a negative impact on cash holding, albeit the coefficient is very small considering that the variation coefficient has to be between zero and one. Firms with high cost of debt increase cash holding, which might be explained by a substitution effect. These firms also exhibit a slower CCC.

\subsection{Granger causality tests and impact multipliers}

We test the causal relationships between cash holding, the CCC, trade credit and short-term bank finance. Table 4 shows Granger causality tests based on the GMM estimates, which underline that the CCC and trade credit influence short-term bank finance, whereas cash holding does not have a causal effect. Cash holding in turn is driven by the CCC and trade credit. All three endogenous variables affect liquidity, and cash holding and the CCC affect trade credit. Granger causality tests reveal that the four variables are endogenous and interrelated; thus, using the CCC as an explanatory variable to explain cash holding is misleading (e.g. Deloof, 2001). To obtain a more precise estimate about the underlying dynamics, we calculate impact multipliers based on the GMM estimates and derive impulse response functions and cumulated impulse response functions. Impulse response functions indicate the response of one variable if another variable changes marginally. We use this methodology to isolate significant impulse-response relationships, which we can interpret as demand or supply-side effects. Using a bootstrapping approach that considers the panel data structure, the original dataset is re-sampled 800 times and the estimated coefficients are obtained. The impact multipliers are calculated based on the 800 point estimates. The percentiles of impact response functions and cumulated impact response functions refer to the respective bootstrapping distribution.

To illustrate the dynamics of the panel VAR, Table 4 summarises cumulated impulse response functions for different periods after the incremental shock. Only a few impulse responses are significant and have a relevant economic impact. The main benefit of using impulse response functions compared to analysing the coefficients in Table 3 is that effects can be isolated. We interpret the impulse-response relationships as either demand or supply-side driven. The supply-side

Table 5

Mismatch of expectations: cash-rich versus average firm.

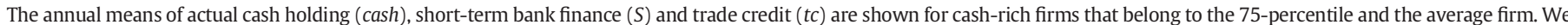

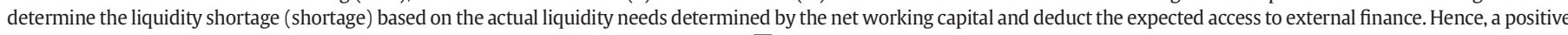

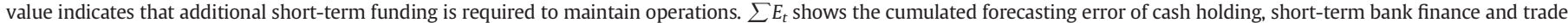
credit.

\begin{tabular}{|c|c|c|c|c|c|c|c|c|c|c|c|c|c|c|}
\hline \multicolumn{7}{|c|}{ Cash-rich firms } & \multicolumn{8}{|c|}{ Average firm } \\
\hline Year & cash & $\Sigma E_{t}($ cash $)$ & $S$ & $\Sigma E_{t}(S)$ & tc & $\Sigma E_{t}(t c)$ & Shortage & cash & $\Sigma E_{t}($ cash $)$ & $S$ & $\Sigma E_{t}(S)$ & tc & $\Sigma E_{t}(t c)$ & Shortage \\
\hline 1991 & 0.271 & 0.001 & 0.259 & 0.000 & 0.128 & 0.000 & 0.003 & 0.103 & -0.001 & 0.250 & 0.001 & 0.137 & 0.000 & 0.023 \\
\hline 1992 & 0.290 & 0.003 & 0.251 & 0.000 & 0.119 & 0.000 & 0.010 & 0.113 & -0.001 & 0.248 & 0.001 & 0.133 & 0.000 & 0.035 \\
\hline 1993 & 0.310 & 0.004 & 0.249 & 0.001 & 0.122 & 0.000 & 0.011 & 0.126 & -0.003 & 0.238 & 0.001 & 0.136 & 0.001 & 0.048 \\
\hline 1994 & 0.301 & 0.005 & 0.225 & 0.001 & 0.122 & 0.000 & 0.012 & 0.128 & -0.004 & 0.233 & 0.001 & 0.140 & 0.002 & 0.069 \\
\hline 1995 & 0.300 & 0.007 & 0.236 & 0.001 & 0.124 & -0.001 & 0.018 & 0.124 & -0.006 & 0.239 & 0.002 & 0.142 & 0.004 & 0.083 \\
\hline 1996 & 0.325 & 0.008 & 0.240 & 0.002 & 0.126 & -0.001 & 0.016 & 0.130 & -0.009 & 0.248 & 0.003 & 0.142 & 0.006 & 0.083 \\
\hline 1997 & 0.335 & 0.011 & 0.252 & 0.002 & 0.118 & -0.001 & 0.013 & 0.140 & -0.009 & 0.253 & 0.004 & 0.140 & 0.007 & 0.083 \\
\hline 1998 & 0.374 & 0.013 & 0.250 & 0.003 & 0.111 & 0.000 & 0.011 & 0.146 & -0.010 & 0.255 & 0.005 & 0.135 & 0.007 & 0.089 \\
\hline 1999 & 0.364 & 0.014 & 0.230 & 0.000 & 0.106 & -0.002 & 0.011 & 0.141 & -0.011 & 0.237 & 0.003 & 0.128 & 0.007 & 0.093 \\
\hline 2000 & 0.407 & 0.016 & 0.178 & 0.000 & 0.084 & -0.003 & 0.005 & 0.160 & -0.011 & 0.216 & 0.002 & 0.116 & 0.007 & 0.083 \\
\hline 2001 & 0.428 & 0.017 & 0.178 & 0.001 & 0.081 & -0.001 & 0.017 & 0.163 & -0.012 & 0.219 & 0.002 & 0.110 & 0.006 & 0.117 \\
\hline 2002 & 0.410 & 0.028 & 0.196 & 0.005 & 0.089 & -0.003 & 0.011 & 0.163 & -0.011 & 0.227 & 0.003 & 0.110 & 0.006 & 0.115 \\
\hline 2003 & 0.408 & 0.036 & 0.221 & 0.004 & 0.107 & -0.003 & 0.019 & 0.164 & -0.009 & 0.239 & 0.004 & 0.117 & 0.007 & 0.119 \\
\hline 2004 & 0.435 & 0.041 & 0.202 & 0.007 & 0.096 & -0.005 & 0.014 & 0.182 & -0.006 & 0.230 & 0.003 & 0.113 & 0.007 & 0.124 \\
\hline 2005 & 0.441 & 0.045 & 0.173 & 0.007 & 0.084 & -0.005 & 0.024 & 0.188 & -0.004 & 0.217 & 0.002 & 0.107 & 0.006 & 0.143 \\
\hline 2006 & 0.436 & 0.060 & 0.158 & 0.006 & 0.075 & -0.010 & 0.037 & 0.186 & -0.002 & 0.208 & 0.001 & 0.104 & 0.005 & 0.164 \\
\hline 2007 & 0.422 & 0.085 & 0.167 & 0.006 & 0.078 & -0.003 & 0.056 & 0.179 & 0.000 & 0.206 & -0.001 & 0.100 & 0.003 & 0.156 \\
\hline 2008 & 0.400 & 0.086 & 0.195 & 0.025 & 0.087 & -0.003 & 0.090 & 0.164 & 0.000 & 0.213 & 0.000 & 0.101 & 0.000 & 0.166 \\
\hline
\end{tabular}




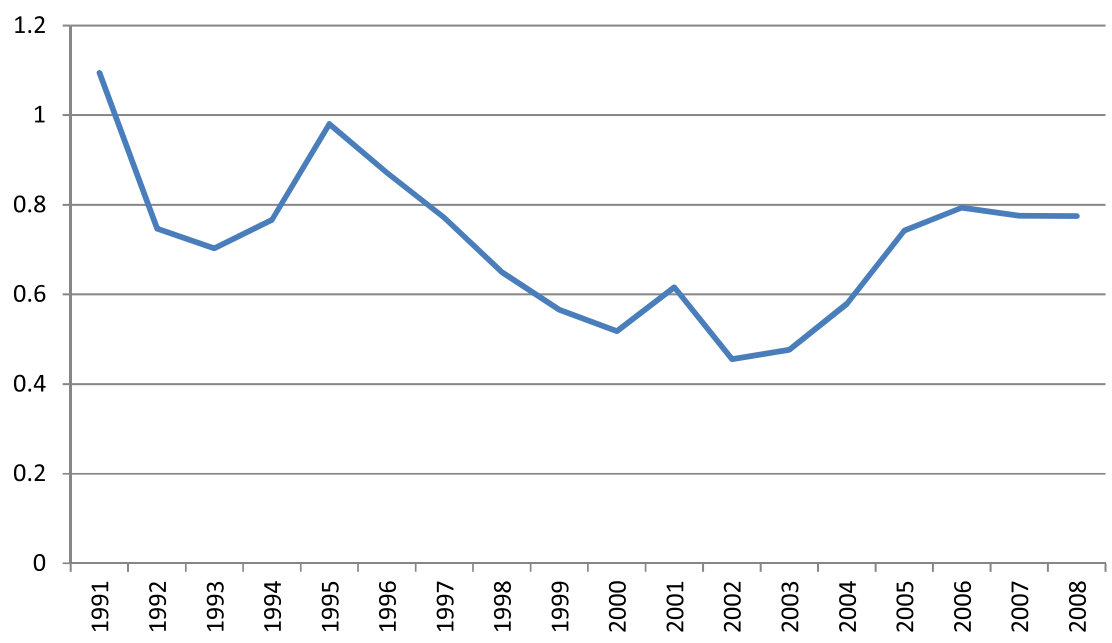

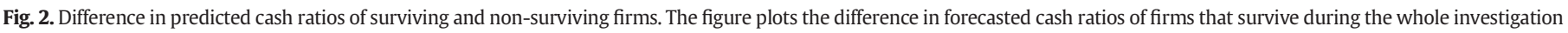
period compared to non-surviving firms. The result is shown in percentage points.

argument focuses on the supply of short-term finance, whereas the demand-side argument highlights the firm's perspective and the demand for liquidity.

Focusing on the supply-side effects of access to short-term bank finance and trade credit, the model makes the following predictions: (1) An increase in trade credit by $1 \%$ increases the level of short-term bank finance by $0.64 \%$ (cumulative effect after eight years); hence, the finding supports the complementary nature of trade credit and shortterm bank finance (Bias \& Gollier, 1997; Burkart \& Ellingsen, 2004). From the perspective of banks, an increase in trade credit signals private information of suppliers, which reduces the information asymmetry between the firm and the bank, which in turn improves access to bank finance. (2) Cash holding has a positive impact on trade credit, which shows that suppliers could consider cash as a positive signal concerning the firm's ability to pay back the trade credit offered.

Isolating the demand-side effects that explain the need for cash holding and other sources of short-term finance, the cumulated impulse response functions illustrate the following relationships. (1) Firms facing a higher liquidity need due to a longer CCC increase cash holding. (2) On a similar note, a slower CCC triggers more trade credit, which we interpret as a demand-side effect, as firms with high liquidity needs and financial distress tend to rely more on trade credit, which is relatively expensive. In addition, we observe two demand-side effects, which could be interpreted in the context of agency theory. The cash holding literature focuses on agency costs related to cash holding in the context of long-term decisions such as mergers and acquisitions (Harford, 1999; Graham \& Harvey, 2001). Even in the short-term, agency costs could be relevant in the context of working capital management, for managers that have additional cash or other sources of funding might not be willing to make the effort to improve the CCC. (3) The impulse response functions illustrate that more cash holding increases the CCC, (4) and an increase in trade credit has an even stronger effect. In contrast, additional short-term bank finance does not cause an increase in the CCC, which can be explained by the monitoring role of banks that define and control liquidity measures.

\subsection{Out-of sample forecasts and cash-rich firms}

Based on the panel VAR, we forecast the level of cash holding and compare fitted values to actual cash holding over time to detect any inconsistencies due to parameter instability or other time related unobserved variables. The parameters seem to be stable, and the model fit does not depend on the time period selected. To check whether the predictions are reliable, we determine one-step-ahead forecasts. Table 5 shows cumulated forecasting errors, which indicate whether the model over- or understates the respective dependent variable. The cumulated forecasting error in 2008, which refers to the whole period from 1991 to 2008, reveals that the model forecasts cash holding $\left(\sum E_{t}(\right.$ cash $\left.)\right)$, short-term bank finance $\left(\sum E_{t}(S)\right)$ and trade credit $\left(\sum E_{t}(t c)\right)$ with great precision.

However, isolating firms with high cash holding defined as above the 75-percentile in 1988 uncovers that the model understates the stockpiling of cash by cash-rich firms. These firms increased cash ratios from $27.1 \%$ to $40.0 \%$. Accordingly, the observed increase was 12.9 percentage points; however, the model made a cumulative forecasting error of +8.6 percentage points (shown in year 2008 in Table 5). This means that the model predicted that cash holding of cash-rich firms would increase by 4.3 percentage points (i.e. 12.9-8.6), which understates the actual accumulation of cash. The observed increase in average cash holding as shown in Fig. 1 is mainly due to the rapid accumulation of cash by firms belonging to the 75-percentile in 1988 .

Comparing cash-rich firms to the average firm reveals that there is a substantial mismatch between expected and actual access to short-term bank finance. Table 5 reveals this mismatch in column $\sum E_{t}(S)$ and shows in row 2008 that expected access to bank-finance exceeds the actual access by 2.5 percentage points in the case of cash-rich firms. Accordingly, the increase in cash holding compensates for the lack of access to short-term bank finance. In contrast, trade credit was in line with expectations indicated by $\sum E_{t}(t c)$ in row 2008 reaching only -0.3 percentage points. Cash-rich firms could reduce the risk of a liquidity shortage, defined as actual liquidity in excess of expected access to external finance, through cash holding. The likelihood of a shortfall has increased sharply since the start of the recent financial crisis with cash-rich firms exhibiting a substantially reduced risk compared to the sample average. From a modelling perspective, the panel VAR does not impose any theoretical restrictions, which is both the benefit and weakness of VAR models. On average the panel VAR predicts the increase in cash holding correctly. But some firms face an unexpected shortage of external funding and need to mitigate the risk of liquidity shortages by holding more cash. ${ }^{5}$

\footnotetext{
5 We can show using a panel probit model that the risk of a liquidity shortage can be reduced through cash holding ( $p$-value 0.017 ). In addition, firm size mitigates the risk ( $p$ value 0.000 ) as does profitability ( $\mathrm{p}$-value 0.040 ) - but a high financial leverage increases the likelihood of a shortage ( $p$-value 0.008 ).
} 


\section{Robustness checks}

\subsection{Survivorship bias}

Any panel data study might suffer from a survivorship bias, for some companies are delisted during the investigation period. Mergers and acquisitions are the most likely cause of a delisting. It is possible that the changing number of cross-sectional units has an impact on the empirical outcome; therefore, we distinguish between firms that are listed during the whole investigation period and those that are listed later or delisted. The panel VAR (Eq. (2)) is re-estimated for the two subgroups of firms, and the results do not differ qualitatively. An alternative method is to include the number of years listed as an additional variable of the panel VAR and analyse whether firms with a longer listing history exhibit different levels of the four endogenous variables. The number of years listed does not influence cash holding nor liquidity needs, whereas trade credit and short-term bank finance are significantly affected, albeit the magnitude of influence is very low with coefficients of 0.0002 and 0.0008 respectively. The alleged survivorship bias does not alter our findings, and the listing period has only a minor effect on trade credit and short-term bank finance. This suggests that the period of listings has a negligible impact on cash holding in contrast to Bates et al. (2009). To illustrate the potential survivorship bias, Fig. 2 plots predicted cash ratios for surviving and non-surviving firms. As expected, non-surviving firms exhibit on average lower cash-ratios compared to surviving firms; however, the difference amounts to 0.7 percentage points from 1991 to 2008, which is negligible. Moreover, the difference seems to be stable over time; thus, an alleged survivorship bias cannot explain the increase in cash holding.

\subsection{Cash holding to cover expected operating losses}

Motivated by Opler et al. (1999), who contend that operating losses reduce cash holding, one could argue that firms hold cash to cover future operating losses. Applying a panel probit model that explains whether a firm experiences an operating loss or not, we predict the probability of operating losses. The expected probability is then included into the panel VAR as a predetermined variable. Note that the expected probability in $t$ is based on information available in $t-1$; hence, the variable is weakly exogenous. There is a sharp increase in the expected probability of operating losses from $5.6 \%$ in 1990 to $18.2 \%$ in 2008; however, the partial impact on cash holding is limited with a coefficient of 0.046 ( $p$-value of 0.017 ). Accordingly, even if the predicted probability reaches one, the expected level of cash holding increases only by 0.046 percentage points, which does not explain the substantial increase in cash holding since $2001{ }^{6}$

\section{Conclusion}

This paper focuses on cash holding and its closest substitutes, shortterm bank finance and trade credit. We determine the firm's need for liquidity based on the CCC. A panel VAR approach extends prior empirical models and reveals the dynamic relationship between cash and other short-term sources of funding. Granger causality tests show that all four variables are endogenous and hence single-equation models used in the literature might suffer from an endogeneity bias (e.g. Deloof, 2001). Moreover, impulse response functions can isolate the dynamic impact of an incremental change of one endogenous variable on another. We interpret different impulse-response relations as demand or supply-side driven. Trade credit increases short-term bank finance, which we regard as a supply-side effect based on the signalling theory of trade credit (Bias \& Gollier, 1997; Burkart \& Ellingsen, 2004).

\footnotetext{
${ }^{6}$ Detailed results are available from the authors on request.
}

Additional cash holding triggers an increase in trade credit, which can be viewed as a supply-side effect, as suppliers might be more willing to provide trade credit to firms with higher cash holding. There are two demand-side effects. A short-term liquidity shock causes more cash holding and trade credit; thus, firms do not prefer bank finance in case of unexpected liquidity needs. We also argue that there are two demand-side effects that could be explained by agency theory. The availability of additional cash or trade credit causes a slowdown of the CCC. Therefore, one could argue that firms that have sufficient funding do not improve their CCC in spite of the fact that a faster CCC would create more shareholder value. Improving working capital management takes effort and might alienate customers. Additional short-term bank finance does not have any impact on the CCC, which we explain by the monitoring role of banks and predefined levels of liquidity measures.

The panel VAR can forecast the four endogenous variables accurately; however, the in-sample heterogeneity shows that firms belonging to the 75-percentile in terms of cash holding experience an unexpected decline in short-term bank finance. Firms faced with an unexpected shortage of external funding react by increasing cash holding. The panel VAR and the unexpected decline in short-term bank finance can explain to a large extent the recent increase in cash holding. The robustness checks address a potential survivorship bias and evaluate the impact of operating losses on cash holding.

Our study shows that short-term bank finance improves the liquidity of firms without causing a deterioration of working capital discipline. We observe a pronounced decline in short-term bank finance in the UK, which contributes to the accumulation of cash. From a policy perspective, improving access to short-term bank finance is beneficial, as the substitutes, cash holding and trade credit, cause agency costs due to an increase in the CCC.

\section{References}

Ang, J., \& Smedema, A. (2011). Financial flexibility: Do firms prepare for recession? Journal of Corporate Finance, 17, 774-787.

Arellano, M., \& Bond, S. (1991). Some tests of specification for panel data: Monte Carlo evidence and an application to employment equations. The Review of Economic Studies, 58, 277-297.

Arellano, M., \& Bover, O. (1995). Another look at the instrumental variable estimation of error-component models. Journal of Econometrics, 10, 29-51.

Bates, T. W., Kahle, K. M., \& Stulz, R. M. (2009). Why do U.S. firms hold so much more cash than they used to? Journal of Finance, 64, 1985-2021.

Beltz, J., \& Frank, M. (1996). Risk and corporate holdings of highly liquid assets. working paper.

Bias, B., \& Gollier, C. (1997). Trade credit and credit rationing. The Review of Financial Studies, 10(4), 903-937.

Burkart, M., \& Ellingsen, T. (2004). In-kind finance: A theory of trade credit. The American Economic Review, 94(3), 569-590.

D'Mello, R., Krishnaswami, S., \& Larkin, P. J. (2008). Determinants of corporate cash holdings: Evidence from spin-offs. Journal of Banking E' Finance, 32(7), 1209-1220.

Deloof, M. (2001). Intragroup relations and the determinants of corporate liquid reserves: Belgian evidence. European Financial Management, 7, 375-392.

Ferreira, M. A., \& Vilela, A. S. (2004). Why do firms hold cash? Evidence from EMU countries. European Financial Management, 10(2), 295-319.

Gama, A. P., Mateus, C., \& Teixeira, A. (2008). Does trade credit facilitate access to bank finance? Empirical evidence from Portuguese and Spanish small medium size enterprises. working paper.

Gitman, L. J. (1974). Corporate liquidity requirements: A simplified approach. The Financial Review, 9, 79-88.

Graham, J. R., \& Harvey, C. R. (2001). The theory and practice of corporate finance: Evidence from the field. Journal of Financial Economics, 61, 187-243.

Harford, J. (1999). Corporate cash reserves and acquisitions. Journal of Finance, 54, 1969-1997.

Harford, J., Mansi, S. A., \& Maxwell, W. F. (2008). Corporate governance and firm cash holding. Journal of Financial Economics, 87, 535-555.

Jain, N. (2001). Monitoring costs and trade credit. Quarterly Review of Economics and Finance, 41(1), 89-110.

Jensen, M. (1986). Agency costs of free cash flow, corporate finance and takeovers. American Economic Review, 76, 323-329.

John, T. A. (1993). Accounting measures of corporate liquidity, leverage, and costs of financial distress. Financial Management, 22, 91-100.

Keynes, J. M. (1936). The general theory of employment. interest and money. London: Harcourt Brace.

Meltzer, A. H. (1960). Mercantile credit, monetary policy, and size of firms. Review of Economics and Statistics, 42(4), 429-443. 
Miller, M. H., \& Orr, D. (1966). A model of the demand for money by firms. Quarterly Journal of Economics, 80, 413-435.

Myers, S. (1977). Determinants of corporate borrowing. Journal of Financial Economics, 5 147-175.

Myers, S. C., \& Majluf, N. S. (1984). Corporate financing and investment decisions when firms have information that investors do not have. Journal of Financial Economics, $13,187-221$.

Nadiri, M. I. (1969). The determinants of trade credit in the U.S. total manufacturing sector. Econometrica, 37(3), 408-423.

Nilsen, J. H. (2002). Trade credit and bank lending channel. Journal of Money Credit and Banking, 34(1), 226-253.
Opler, T., Pinkowitz, L., Stulz, R., \& Williamson, R. (1999). The determinants and implications of cash holding. Journal of Financial Economics, 52, 3-46.

Ozkan, A., Ozkan, N., \& N. (2004). Corporate cash holdings: An empirical investigation of UK companies. Journal of Banking and Finance, 28, 2103-2134.

Petersen, M. A., \& Rajan, R. G. (1997). Trade credit: Theories and evidence. The Review of Financial Studies, 10(3), 661-691.

Tobin, J. (1956). The interest elasticity of transactions demand for cash. Review of Economics and Statistics, 38, 241-247.

Wang, Y. -J. (2002). Liquidity management, operating performance, and corporate value: Evidence from Japan and Taiwan. Journal of Multinational Financial Management, 12, 159-169. 